FARKAS TAMÁS - SLÍZ MARIANN szerk., Tulajdonnevek és szótárak. ELTE Magyar Nyelvtudományi és Finnugor Intézet - Magyar Nyelvtudományi Társaság, Budapest, 2020. 63-91. DOI: 10.26546/4892373.5

\title{
Tulajdonnevek a helyesírási szótárakban
}

1. A vizsgálat korpusza. A téma 114 évet fog át, ennyi ideje, 1906-ban jelent meg ugyanis az első magyar helyesírási szótár. Nem meglepő, hogy minden helyesírási szótárban szép számmal előfordulnak tulajdonnevek. Jelen írás figyelembe veszi az összes köznyelvi helyesírási szótárat. Így tehát nem foglalkozik a szaknyelvi helyesírási szótárakkal, illetve az átírási szótárakkal, valamint a kifejezetten iskolai célra készült munkákkal (bár a korai magyar helyesírási szótárak jobbára inkább a diákokat célozhatták meg). Tekintettel van ugyanakkor a feldolgozott munkákhoz kapcsolódó szabályzatra, illetve magyarázó függelékre is a tulajdonnévi vonatkozások szempontjából. Tekintsük először tehát át a feldolgozott forrásokat időrendben, néhány alapvető jellemzőjük vagy egyedi sajátságuk megjegyzésével:

KELEMEN BÉla 1906. A magyar helyesirás kis szótára. A hivatalos iskolai helyesírás alapján. Athenaeum, Budapest. 6×14 cm, 172 lap (szótár: 5-159). [Közvetlen szemrevételezésre az 1914. évi, 6. kiadás került; ez az 1907. évi, 2. kiadás utánnyomásának tekinthető. A kötethez függelék is tartozik.]

HORVÁTH ENDRE 1913. A magyar helyesírás szótára és szabályai. Az iskolai helyesirás alapján. Athenaeum, Budapest. $14 \times 21 \mathrm{~cm}, 288$ lap (szótár: 5-258). [A kötethez szabályzat is tartozik.]

BALASSA JÓZSEF 1929. Az egységes magyar helyesirás szótára és szabályai. Budapesti Korrektorok és Revizorok Köre, Budapest. 12×17 cm, L+288 lap (szótár: 1-288). [Bevett rövidítése: NyomdH. A kötethez szabályzat is tartozik. $]^{1}$

BOGNER JÓZSEF 1939. A magyar helyesirás szabályai és szótára. Jugoszláviai Magyar Népkönyvtár. Globus Nyomda, Petrovgrád [= Nagybecskerek]. $12 \times 18 \mathrm{~cm}, 115$ lap (szótár: 26-111).

MAgYAR TUdOMÁNYOS AKAdÉMIA 1950. A magyar helyesirás szabályai. 9., átdolgozott és bővített kiadás. Akadémiai Kiadó, Budapest. $14 \times 20$ cm, 185+4 lap (szótár: 47-185). [A szótár a szabályzat mellékleteként jelent meg. Bevett rövidítése: AkH. 1950.]

MAGYAR TUdOMÁNYOS AKAdÉMIA 1954. A magyar helyesírás szabályai. 10., átdolgozott és bővített kiadás. Akadémiai Kiadó, Budapest. $14 \times 20$ cm, 268 lap (szótár: 89-265). [A szótár a szabályzat mellékleteként jelent meg. Bevett rövidítése: AkH. 1954.]

${ }^{1}$ A szótári apparátus itt utal először lexikográfiai szempontból professzionális munkára. - A kiadvány szoros kapcsolatban van a BALASSA szerkesztette, de e helyt külön be nem mutatott $A$ magyar nyelvtan és helyesírás kézikönyve. Kis magyar nyelvtan és helyesírás szabályai és szótára címü, a Lingua Kiadónál feltehetöleg az 1940-es években év nélkül, négyszer kiadott, helyesírás terén a NyomdH.-nál szükebb anyagú kézikönyvvel. Továbbá lényegében e két nagyon hasonló kötetből kompilált munka a következő, BALASSA nevét még csak meg sem említő szótár: BODRITS ISTVÁN szerk. 1953. A magyar helyesírás szótára. I. rész. Nyelvtan és helyesirási útmutató. II. rész. Szótár. Testvériség-Egység Könyvkiadóvállalat, Újvidék. 12×17 cm, LXXIX+260 lap. 
Deme LÁszló - FÁBIÁn PÁl 1961. Helyesírási tanácsadó szótár. Terra, Budapest. 14×20 cm, 827 lap (szótár: 17-814). [Közvetlen szemrevételezésre az 1977. évi, 7. kiadás került, ez az 1970. évi, 4. kiadás utánnyomásának tekinthető. Bevett rövidítése: HTSz.] ${ }^{2}$

Szabó T. Attila - BAlogh Dezsö - GÁlffy Mózes - Kelemen Béla szerk. 1978. Magyar helyesirási szótár. Kriterion Könyvkiadó, Bukarest. 12×17 cm, 718 lap (szótár: 103-718).

MAGYAR TUdOMÁNYOS AKADÉMIA 1984. A magyar helyesírás szabályai. 11. kiadás. Akadémiai Kiadó, Budapest. 14×20 cm, 388 lap (szótár: 129-375). [A szótár a szabályzat mellékleteként jelent meg. Bevett rövidítése: AkH. 1984.]

Deme LÁszló - FÁBIÁN PÁL 1988. Helyesírási kéziszótár. Akadémiai Kiadó, Budapest. 14×20 cm, 687 lap (szótár: 13-674). [Bevett rövidítése: HKsz.]

Deme LÁszló - FÁBiÁn PÁl - TÓTh ETELKA 1999. Magyar helyesírási szótár. Akadémiai Kiadó, Budapest. 16×24 cm, XI+587 lap (szótár: 1-574). [DEME-FÁBIÁN 1988 közvetlen utóda, lényegében felújított kiadása. Bevett rövidítése: MHSz.]

LACZKÓ Krisztina - MÁRTONFi AtTiLA 2004. Helyesírás. Osiris Kiadó, Budapest. $14 \times 20 \mathrm{~cm}$, 1539 lap (szótár: 425-1497). [A kötet első része: Tanácsadó, a második része: Szótár. Bevett rövidítése: $\mathrm{OH}$.

BÁRÁNY MARGit 2009. Akadémiai helyesirási szótár. Akadémiai Kiadó, Budapest. $13 \times 20 \mathrm{~cm}$, 1415 lap. $^{3}$

MAgYAR TUdOMÁNYOS AKADÉMIA 2015. A magyar helyesírás szabályai. 12. kiadás. Akadémiai Kiadó, Budapest. 14×20 cm, 611 lap (szótár: 141-577). [A szótár a szabályzat mellékleteként jelent meg. Bevett rövidítése: AkH. 2015.] ${ }^{4}$

TÓTH ETELKa 2017. Magyar helyesirási szótár. A magyar helyesirás szabályai tizenkettedik kiadása szerint. Akadémiai Kiadó, Budapest. 16×24 cm, VIII+586 lap. [Érdemben eltér DEMEFÁBIÁN-TÓTH 1999-től, önálló münek tekinthető. Ajánlott rövidítése: MHSz. ${ }^{2}{ }^{5}$

2. A vizsgált kategóriák. A vizsgálat az MTA 2015 tulajdonnévi kategóriáit veszi alapul: személynevek, állatnevek, tárgynevek, földrajzi nevek, csillagászati nevek, intézménynevek, márkanevek, kitüntetés- és díjnevek, címek, egyéb tulajdonnevek. A feldolgozás is ezt a rendet követi, szemben a névtanban megszokott személynév, földrajzi név stb. sorrenddel. Minthogy a személy-állat-tárgy kategóriák szemantikailag is szorosabban összetartoznak, ez a megközelítés ontológiai szempontból is erősen indokolható.

A szótárak átnézése a következő általános tanulságokkal szolgált:

1. A szótárak folyamatosan bővülnek, nőnek, ezért nő a bennük feldolgozott tulajdonnévi anyag is.

2. A szótári apparátus folyamatosan csiszolódik, kikristályosodik. Az eleinte némiképp zavaros apparátus először túlbonyolódik, majd a nyolcvanas években letisztul. Az ötvenes évektől kezdődően egyértelmüen szerves fejlődésről beszélhetünk.

3. Egyre több tulajdonnévtípus, tulajdonnévi kategória jelenik meg a szótárakban (részletesen 1. alább).

${ }^{2}$ E helyesírási szótár elkészítése során sok, a helyesírási szabályzatban taglalhatónál finomabb részletkérdést szabályozott a helyesírási bizottság (FÁBIÁN szerk. 1962, újrakiadása: FÁBIÁN szerk. 1972).

${ }^{3}$ A kiadvány alig tekinthető helyesírási szótárnak, híján van bárminemü struktúrának, puszta szó(alak)felsorolás. A benne található hibák száma is igen nagy.

${ }^{4}$ A szabályzatban nem mutatkoztak érdemi változások, így alapvetően csupán a szótári részt mutatjuk be.

${ }^{5}$ Az azonos cím ellenére DEME-FÁBIÁN-TóTH 1999-hez képest igen sok a változás. Az alábbiakban csak ilyen változásokat mutatunk be. 
3. A részletes adatok. Tekintsük át tehát az egyes tulajdonnévi kategóriákat időrendben a szótárak konkrét példáin. A példák kiválasztása szemléletességre és típusonként teljességre törekvő, ugyanakkor az alábbiak éppen ezért nem tekinthetők puszta adatközlésnek: a beszédes példák megfelelő összeválogatása adja magát az elemzést. Minthogy kiragadott példákat mutatunk be, az egyes szótárak tipográfiájától eltekintünk - inkább zavaró, mint informatív lett volna reprodukálásuk. Azokat a példákat, amelyeket egy adott szótár törölt az előzménykiadványhoz képest, áthúzás jelöli a továbbiakban.

3.1. Személynevek. Személynevek mindegyik szótárban előfordulnak.

KELEMEN 1906-ban utónevek, egyelemü nevek (hírességek, fiktív személyek nevei) és teljes nevek jelennek meg, ragozási mintával:

Adél (Adélnak v. ritkb. Adélnek)

Aeschylus v. Aiskhylos

Aesopus (Ezópus); aesopusi mese

A függelékben:

Petöfi Sándor, Baróti Szabó Dávid

József, Vince

Szent István, Nagy Lajos
Anyégin (nem: Onegin)

gróf Andrássy Gyula

Bacchus v. Bakkhos

a Habsburg család

Isten: Úr, Teremtö, Megváltó

HORVÁTH 1913-ban családneveket, illetve összetételeket is találunk:

Abaffy nemescsalád; Abafi Lajos, iró

Ábrahám

Achilles, Achilles-in, Achilles-sarok

A szabályzatban:

Csokonai Vitéz Mihály

Semsei Semsey Andor gróf

Nagy Lajos

Kis Károly

Vak Béla

Szent István

szent András adonáj v. Adonáj zs: Uram! Jehova

Adorján v. Andor

Bocskay-család, Bocskay brigadéros

BALASSA 1929:

Ábel, tn, -t, -je

Ágh, csn

Achilles, th, $-t$, - $e$

A szabályzatban:

Vörösmarty Mihály

Baróti Szabó Dávid

Vitéz Nagy János

a nagy Napóleon

a kis Kovács

Végzet

Hadúr

Isten: Gondviselés, Mindenható, Megváltó

Hóditó Vilmos

Szent István

Isten: Úr, Mindenható, Örökkévaló, Megváltó

Nagy Lajos

Szüz Mária

Boldog Margit 


\section{BOGNER 1939:}

Achilles

Adél (nem Adéle)

Aeshylus v. Aiskhylos
Ágoston: Augusztinus

Ármány isten neve

Balogh; Baloghy

A szabályzatban:

Puncsec, Sztojadinovics, Hajdukvelykovics, Szveti Hubert és nem Punčec, Sveti Hubert

Boldog Krizinus, Nagy Frigyes, Hatalmas Dusán, Oroszlánszívü Richárd Achilles és nem Achill; Ovidius és nem Ovid; Homérosz és nem Homér Zeus, Hadur, Wotan, Dajbog Mindenható, Megváltó, Üdvözitö Ady Endre, Szabó Dezsö, Jovánovics Milán

MTA 1950:

Achilles; Achilles-sarka valakinek Ádám Ágost: Augustus Aiskhylos v. Aeschylus Allah, Allahot, Allahhal Amade (csn.); Amadé (kn.) Anonymus tn. Apafi

Árpád-család Árpád-ház Árpád-házi Árpád-kori Atilla v. Attila (hun király) Attila v. Atilla megváltó; a Megváltó (= Krisztus) Messiás (= Krisztus)

A szabályzatban:

Petőfi Sándor, Ady Endre, Móricz Zsigmond

Hadúr, Jupiter, Zeus

Könyves Kálmán, Nagy Péter, Hóditó Vilmos, Bölcs Salamon, Szent László Isten, Mindenható, Szentlélek, Szentháromság, Boldogasszony a nagy Napóleon, a tengerjáró Kolumbus

MTA 1954:

Achilles-sarka valakinek
Ádám
Adolf
Ady Endre
Aeneas

Allah, Allahot, Allahhal Anatole France Anjou, Anjouk Anonymus Attila

A szabályzatban bemutatott kategorizáció: család- és keresztnevek; történelmi személyek nevének állandó jelzője; a mitológia és a vallás személynévként használt nevei.

\section{DEME-FÁBIÁN 1961:}

Ábel, Ábellal v. Ábellel Achilles l. Akhilleusz
Achilles-sarka valakinek

Adrien, Adriennel 
Ady: Ady Endre, Adyval, az Adyak és

Adyk; - adyas v. adys, Ady Endré-s;

$\mapsto$ Ady-vers; - Ady-versbeli
Aiszkhülosz, Aiszkhülosszal; - aisz-

khüloszi; elv.: Aisz-khü-losz

Aiszóposz, Aiszóposszal; - aiszóposzi,

de: Ezópus fabulái, ezópusi mesék

SZABÓ T. et al. 1978:

ádám-: ádámcsutka, ádámkosztüm

Adonisz, Adonisszal; adoniszi

Albert, Alberttal v. Alberttel

Allah, Allahot, Allahhal

Aeneas, Aenesszal; aeneasi

Aiszkhülosz, Aiszkhülosszal; aiszkhü-

loszi; elv.: Aisz-khü-losz

Arany: Arany János, Arannyal,

Aranyt; aranyi; Arany János-i,

Arany-szerü, Arany-vers

A szabályzatban bemutatott kategorizáció: vezetéknevek és keresztnevek; asszonynevek; történelmi személyek nevének állandó jelzője; a mitológia és a vallás fogalomkörébe tartozó, személynévként használt nevek.

MTA 1984:

Achilles-sarka valakinek; de:

Akhilleusz

Áchim L. András

Adrienn, Adriennel, Adriennél

Ady: Ady Endre, az Adyak és Adyk;

adyas v. adys, Ady Endré-s; Ady-

-vers; Ady-versbeli; Ady Endre utca

Aeneas, Aeneasszal

Allah, Allahot, Allahhal

Amadé (keresztnév), Amadéval

A szabályzatban bemutatott kategorizáció: családnevek (vezetéknevek) és keresztnevek (utónevek); asszonynevek; a mitológia és a vallás személynévként használt nevei.

DEME-FÁBIÁN 1988:

Ábel, Ábellal v. Ábellel

Achilles-sarka valakinek; de: Akhilleusz

Adrienn (keresztnév), Adriennel, Adriennél

Ady: Ady Endre, Adyval, az Adyak és

Adyk, adyas v. adys, Ady Endré-s;

Ady-vers, Ady-versbeli; Ady Endre

utca

Aiszkhülosz, Aiszkhülosszal, aiszkhü-

loszi; elv.: Aisz-khü-losz

Aiszóposz, Aiszóposszal, aiszóposzi;

de: Ezópus fabulái, ezópusi mesék

DEME-FÁBIÁN-TóTH 1999 nem mutat változást DEME-FÁBIÁN 1988-hoz képest.

LACZKÓ-MÁRTONFI 2004: csak itt található az idegen nevek kiejtésére vonatkozó utalás.

Abdullah: Abdullahhal, abdullahi

Abbado [abbádó] Abbadóval, abbadói

I Claudio Abbado

Abe Kóbó: Abe Kóbóval, Abe Kóbó-i

|| Abe Kóbó-regény
Ábel: Ábellel, ábeli

Achilles-[ahillesz-] \{A-chil-les- $\} \rightarrow$

Akhilleusz || Achilles-ín, Achilles-

-in-szakadás, Achilles-sarok 
Adamis: Adamissal, adamisi $\|$ Adamis Anna

Adonáj: Adonájjal, adonáji

Adonisz (utónév) Adonisszal, adoniszi $\| \rightarrow$ | valóságos
Adónisz 'Kinürasz király és leánya, Mürrha fia' (latinul Adonis) Adónisszal, adóniszi || adóniszi kólon, adóniszi sor

Afanaszjevics $\| \rightarrow \mid$ Bulgakov

A kötet Tanácsadó részében bemutatott kategorizáció: családnevek; utónevek; házassági nevek; becenevek; ragadványnevek; müvésznevek, írói álnevek; a mitológia és a vallás személynévként használt nevei; nickek.

BÁRÁNY 2009:

$\begin{array}{ll}\text { Ábel } & \text { Ady Endré-s } \\ \text { Achilles, Akhilleusz } & \text { Ady Endre utca } \\ \text { Achilles-ín } & \text { Adyk } \\ \text { Achilles-sarok (valakinek az Achilles- } & \text { Ady-kötet } \\ \quad \text {-sarka) } & \text { Ady-kutatás } \\ \text { Áchim L. András } & \text { adys } \\ \text { Adolfka } & \text { Ady-vers } \\ \text { Ady } & \text { Ady-versbeli } \\ \text { Ady Endre } & \text { Akhilleusz }\end{array}$

MTA 2015:

Abigél, Abigéllel v. Abigéllal Achilles-in; Achilles-in-szakadás -vers; Ady-versbeli; Ady Endre utca

Achilles-sarka valakinek; de: Akhilleusz

Adrienn, Adrienn-nel, Adrienn-nél Ady: Ady Endre, az Adyak és Adyk; adyas v. adys, Ady Endré-s; AdyAeneas (görögül Aineiasz), Aeneasszal Allah, Allahot; Allahhal Amadé (utónév), Amadéval

TÓTH 2017:

Achilles; elv.: A-chil-les; l. Akhilleusz

Adrienn (utónév), Adrienn-nel, AdriAchilles-in; Achilles-in-szakadás enn-nél

Achilles-sarok, Achilles-sarka valakinek

Áchim: Áchim L. András; elv.: Ady: Ady Endre, Adyval, adyas v. adys, Ady Endré-s; Ady-vers, Ady-versbeli; Ady Endre utca Á-chim; Áchim-ügy

3.2. Állatnevek. Az állatnevek írása talán a leghektikusabb a különféle helyesírási szótárakban. 1913-ban jelennek meg először, de 1950-ig a szótárakban csak kis kezdőbetüs példák vannak (pl. bodri). 1929 óta a szabályzatokban előfordulnak nagy kezdőbetüs állatnevek. Szótárakban nagy kezdőbetüs állatnévi példák csak 2004 óta bukkannak fel (BÁRÁNY 2009 kivételével). 
KELEMEN 1906-ban egyáltalán nem találhatók állatnevek.

HORVÁTH 1913-ban megjelenik néhány, kis kezdőbetüs példa:

bodri

riska

BALASSA 1929 ellentmondásos - a szótárban kis, a szabályzatban nagy kezdőbetűvel ad példákat:

bodri

A szabályzatban:

Bodri Ráró

BOGNER 1939 csak a szabályzatban említ állatneveket:

Bimbó, Morzsa, Pici, Sárga

MTA 1950 is BALASSA 1929 kettősségét követi.

riska (tehén)

A szabályzatban:

Bodri, Sajó, Cirmos, Villám, Fecske,

Csákó, Bimbó

MTA 1954 csak a szabályzatban hoz állatneveket:

Bimbó, Bodri, Cirmos, Csákó, Fecske,

Sajó, Villám

DEME-FÁBIÁN 1961-ben nincs állatnévi példa.

SzABÓ T. et al. 1978 csak a szabályzatban hoz állatneveket:

Bimbó, Bodri, Cirmos, Csákó, Fecske,

Sajó, Villám

MTA 1984 ismét csak a szabályzatban foglalkozik a kérdéssel:

Bimbó, Csákó; Fecske, Villám; Bodri,

Zsoli; Cili, Cirmos

DEME-FÁBIÁN 1988-ban sincs állatnévi példa.

DEME-FÁBIÁN-TóTH 1999 nem mutat változást DEME-FÁBIÁN 1988-hoz képest.

LACZKÓ-MÁRTONFI 2004:

Bodri: Bodrival, bodris

Ráró: Ráróval, rárós 
A szótár Tanácsadó részében:

Bakróházi Mirr-murr Szepi Józsefvárosi Kócos Pajtás Mihály

Bimbi, Cimi, Cindri, Csuppi, Susu, Szipa, Szuszmók, Tunyó Akela, Bagira, Bambi, Csí, Kele
Amazon, Báró, Bundás, Gyanús, Holló, Ilyesmi...

Bodri kutya, Cili cica, Ráró lovam, Riska tehén, Pityu papagáj,

Kavicska teknös

BÁRÁNY 2009-ben nincs állatnévi példa.

MTA 2015:

Bodri: Bodri kutya, Bodrival

Cirmos (állatnév); de: cirmos cica

TóTH 2017:

Bodri, Bodrival: Bodri kutya, Bodrival

Cirmos (állatnév); de: cirmos cica

3.3. Tárgynevek. Tárgynevekre példát először 1999-ből találni (pl. Szent Korona). A tárgynévi kategória 2004-től egyértelmü csupán. KELEMEN 1906, HoRVÁTH 1913, BALASSA 1929, MTA 1950, MTA 1954, DEME-FÁBIÁN 1961, SZABÓ T. et al. 1978, MTA 1984 és DEME-FÁBIÁN 1988 tehát nem vesz fel tárgynévi kategóriát.

DEME-FÁBIÁN-TÓTH 1999-ben jelennek meg először a tárgynevek, bár gyanítható, hogy a nagy kezdőbetüs írásmód valójában a szakralitásra utal, s nem tárgynév voltuk miatt kapnak nagy kezdőbetüt:

Szent Jobb (nemzeti ereklye)

Szent Korona-tan

Szent Korona (nemzeti ereklye)

Kategóriaként LACZKÓ-MÁRTONFI 2004 tárgyalja elsőként a tárgyneveket:

Szent [...] Szent Jobb

Szent Korona || Szent Korona-tan
Titanic [titanik] titanicos || Titanic-

-katasztrófa

A kötet Tanácsadó részében bemutatott kategorizáció: hajónevek; mozdonyok, léghajók, repülőgépek neve; ürjármüvek és más ürobjektumok neve; vonatjáratok neve; hálózati számítógépek neve.

BÁRÁNY 2009:

Szent Jobb (nemzeti ereklye)

Szent Sir

Szent Korona (nemzeti ereklye)

MTA 2015:

Excalibur (Artúr kardja; fegyvernév)

Szent Jobb (nemzeti ereklye)

Szent Korona (nemzeti ereklye); Szent

Korona-tan

A szabályzatbeli kategorizáció LACZKÓ-MÁRTONFI 2004-et követi.

TóTH 2017 pontosan követi MTA 2015-öt. 
3.4. Földrajzi nevek. Földrajzi nevek mindegyik szótárban előfordulnak.

KELEMEN 1906 országok, vizek, földrészek, közterületek, települések, megyék neveit mutatja be:

$\begin{array}{ll}\text { Abesszinia (Abisszinia); abessziniai } & \text { Al-Duna; aldunai } \\ \text { Ádriai-tenger } & \text { Andrássy-úti } \\ \text { Afrika; afrikai } & \text { Bács-Bodrog vármegye; de: } \\ \text { Akácfa-utca } & \text { bácsmegyei } \\ \text { az Akropolis } & \text { Grác [-ban, -ot]: gráci } \\ \text { Alcsút, községnév; alcsúti } & \end{array}$

A függelékben:

Rákóczi-út, Múzeum-körút, KirályArany János utcai, Deák Ferenc téri -utca, Petöfi-tér

Arany János utca, Deák Ferenc tér, Budapest; budapesti Ferenc József hid

Duna

Ferenc-körúti, Lónyay-utcai, BudaMagyarország; magyarországi Magas Tátra utcai

Fekete-tenger

bécsiutcai, királyutcai

HORVÁTH 1913-ban települések, megyék, országok, térszínek, vizek, közterületek stb. nevei találhatók meg:
Abaúj-Torna vármegye v. megye, abaújmegyei v. abaújtornamegyei Abbazia (-ban, -ba) (v. Abbázia) Abesszinia, abessziniai Abruzzók: az Appeninek fennsíkja Afrika, Dél-Afrika, délafrikai Al-földr:: Al-Duna, az Alföld

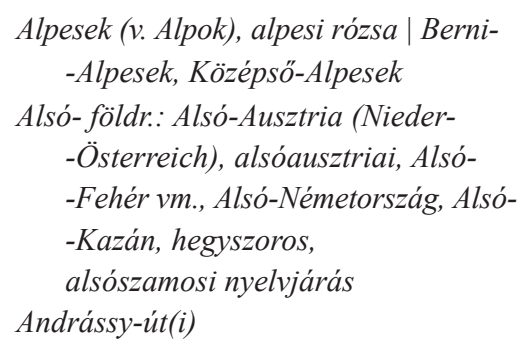

A szabályzatban bemutatott kategorizáció: helységnevek; megyék neve; országok, földterületek, világrészek és szigetek neve; hegységek neve; vizek neve; utcák, terek, városrészek neve; épületek, hidak, szobrok neve.

BALASSA 1929:

\author{
Abbazia, ..ában; abbaziai \\ Abesszínia, abesszíniai \\ Abony, hn, -ban: abonyi
}

Adria, Adriai tenger [Adriai-tenger]

Afrika, afrikai; Dél-Afrika, Észak-

-Afrika, délafrikai, északafrikai 
A szabályzatban:

Angolország
Székesfehérvár, Balatonfüred, Duna-
földvár, Magyaróvár
Bécs-Újhely, Majna-Frankfurt, Baden-
-Baden
Észak-Amerika, Dél-Afrika, Nyugat-
-Magyarország, Kelet-Európa
északamerikai, délafrikai,
nyugatmagyarországi
Zala (vár)megye, Fejér (vár)megye
Erzsébet körút, Váci ucca, Ferenc Jó-
zsef tér
Atlanti óceán, Földközi tenger, Fekete
tenger, Vörös tenger

Belváros, Viziváros, Józsefváros

Lánchíd, Margithid, Erzsébethíd

Margitsziget, Csepelsziget

Gellérthegy, Sashegy, Hármashatár-

-hegy

Ferenc József hid

margitszigeti, józsefvárosi

Petöfi téri, Deák Ferenc uccai

Duna

Budapest; budapesti

Tátra

Gellérthegy

\section{BOGNER 1939:}

Abesszinia, abessziniai

Adria, adriai-tenger

Afrika, afrikai, Délafrika, délafrikai Alcsi, az alcsi bíró (nem: az alcsii bíró)

alföld, de: az Alföld

Algír, algíri

A szabályzatban:

Petrovgrád, Noviszád, Lyubisa

Bácska Palánka és nem Bačka Palanka

sziboticai Danicsityev út és nem suboticai Daničićev put

MTA 1950:
Alpesek v. Alpok; alpesi tájék Altaj hegység; urálaltaji nyelvek Amerika; Észak-Amerika; amerikai, észak-amerikai tér: Petöfi-tér, Szabadság-tér; [...] Petöfi-téri, Vörösmarty-téri, de: szabadságtéri, szénatéri

Karagyorgye tér Jugoszlávia, Sumadija, Száva, Alföld,

Dunántúl, Balaton, Nis,

Kragujevác, Délszerbia
Alföld, Nagy-Alföld, Kis-Alföld

alföldi, nagyalföldi, kisalföldi

Algir

algíri

Alpesek v. Alpok

Bakony, Hernád, Balaton

Sztálin-út, Rákóczi-tér, Marx-tér 
MTA 1954:

$\begin{array}{ll}\text { Abesszinia } & \text { afrikai } \\ \text { abesszíniai } & \text { Afrika-kutató } \\ \text { Adria } & \text { Albán Népköztársaság } \\ \text { Adriai-tenger } & \text { Alföld: Nagyalföld, Kisalföld } \\ \text { adriai-tengeri halászat } & \text { Alpokv. Alpesek } \\ \text { Afganisztán } & \text { Alsó-: Alsódabas } \\ \text { Afrika } & \text { Antarktisz: elv.: An-tark-tisz }\end{array}$

A szabályzatban bemutatott kategorizáció: országok neve; országrészek, tájegységek neve; vármegyék neve; közigazgatási egységek többelemü neve; helységnevek; városrészek neve; utcák és terek neve.

\section{DEME-FÁBIÁN 1961:}

Abbázia, Abbáziában;-abbáziai

Abesszinia, Abessziniában;-abessziniai

Adria, az Adrián; - adriai

Adriai-tenger, az Adriai-tengeren; adriai-tengeri, Afrika, Afrikában; - afrikai $\mid \rightarrow$ Afrika-kutatás, Afrika- -vadász; - Afrika-vadászi felszerelés $\mid \leftarrow$ Dél-Afrika, Észak-

-Afrika; - dél-afrikai, észak-afrikai

Albán Népköztársaság

Algír (arabul Al-Dzsazáir), Algírban;

- algíri

SZABÓ T. et al. 1978:

Abesszinia; abessziniai

Adeni-öböl; adeni-öböli

Afrika; afrikai; Afrika-kutató; Dél-

-Afrika; dél-afrikai

Alexandria, Alexandriába; alexandriai;

elv.: Ale-xand-ria

alföld: nagy alföld, román alföld, termékeny alföld; Nagyalföld, Németalföld; Szlovák-alföld Amerikai Egyesült Államok; amerikai egyesült államokbeli; röv.: USA, USA-beli

Antwerpen; antwerpeni

A szabályzatban bemutatott kategorizáció: országok neve; államnevek; országrészek, tájegységek neve; vármegyék neve; közigazgatási egységek többelemü neve; települések neve, helységnevek; városrésznevek; utcák és terek neve.

MTA 1984:

Abesszinia (történeti név); ma: Etiópia Adriai-tenger, adriai-tengeri

Afganisztán, afganisztáni

Afrika, afrikai; Afrika-kutatás | Közép-

-Afrika, közép-afrikai alföld (=síkság); de: az Alföld (magyar tájegység); Havasalföld (történeti tájnév), Kisalföld, Német-alföld; Pó-alföld; Szlovák-alföld 
Algériai Szultánság (történeti), algériai szultánságbeli

Alpok, az Alpokban; Keleti-Alpok; az osztrák Alpok
Alsó-: Alsóörs, alsóörsi; Alsó-Ausztria, alsó-ausztriai

Antarktisz, antarktiszi: elv.: Ant-arktisz v. An-tark-tisz

A szabályzatban bemutatott kategorizáció: egyelemü földrajzi nevek; országnevek, országrésznevek, tájnevek; helységnevek, helységrésznevek; kötőjellel kapcsolt földrajzi nevek; államnevek, gazdasági földrajzi körzetnevek; államrészek nevei; közterületek nevei.

DEME-FÁBIÁN 1988:

Abbázia (szerbhorvátul Opatija), abbáziai

Abesszinia (történelmi név); ma: Etiópia

Abház ASZSZK

Adriai-tenger, adriai-tengeri

Adyliget, adyligeti
Afrika, afrikai; Afrika-kutatás |

Közép-Afrika, közép-afrikai

Aggteleki-cseppköbarlang (= Ba-

radla)

Aix-en-Provence, aix-en-provence- $i$

Albán Szocialista Népköztársaság, al-

bán szocialista népköztársasági

Algír (város; arabul Ed-Dzáir), algíri

\section{DEME-FÁBIÁN-TÓTH 1999:}

Abbázia (horvátul Opatija), abbáziai Abesszinia (tört.); ma: Etiópia

Aggteleki-cseppköbarlang (névváltozat Baradla)

Abhá ASZSZK

Albán Köztársaság, albán köztársasági

LACZKÓ-MÁRTONFI 2004 - megjelennek határon túli magyar tulajdonnevek és tulajdonnévtípusok: ${ }^{6}$

Aachen [áhen] \{Aa-chen\} Aachenben, aacheni

Abaligeti-barlang

Abaúj-Torna vármegye: Abaúj-Torna vármegyében, Abaúj-Torna vármegyei

Abbázia (horvátul Opatija), Abbáziában, abbáziai

Ábrahámhegy (település) Ábrahámhegyen, ábrahámhegyi
Ábrahám-hegy (hegy) Ábrahám-hegyen, Ábrahám-hegyi

Ada község: Ada községben, Ada községi

Afgán Iszlám Állam: afgán iszlám állami

Aggteleki Nemzeti Park: aggteleki nemzeti parki

Ajtósi Dürer sor: Ajtósi Dürer sori Akadémiatelep $\| \rightarrow \mid$ Régiakadémiatelep

A kötet Tanácsadó részében bemutatott kategorizáció: országnevek és államnevek; víznevek, domborzati nevek, terület- és tájnevek, tengerfenék-domborzati nevek; utcanevek.

${ }^{6}$ Az Ada község például a magyarországitól eltérően az Ada város mint központ körüli járást, kistérséget jelöli. 
BÁRÁNY 2009:

Abbázia
Abesszínia (történelmi)
abesszíniai
Abrudbánya
Abruzzók
Afrika

MTA 2015: afrikai

Afrika-kutatás

Afrika-kutató

Afrika-utazó

Alcsi-Holt-Tisza

TÓTH 2017 alapvetően DEME-FÁBIÁN-TÓTH 1999-et követi, de vannak kisebb változtatások, például:

Afrika, afrikai; Afrika-térkép |Közép-Afrika, közép-afrikai

3.5. Csillagászati nevek. Csillagászati nevek mindegyik szótárban előfordulnak.

\section{KELEMEN 1906:}

göncölszekér (csill. munkákban: a

Göncölszekér)

\section{HORVÁTH 1913:}

göncöl, göncölszekér, kisgöncöl

hold, holddal (csill. munkákban: a

Hold, de pl. a Szaturnusznak nyolc holdja van)

A szabályzatban:

Merkúr

BALASSA 1929:

göncölszekér (vö szekér); a Nagy-

-Göncöl és a Kis-Göncöl
Ajka, ajkai

Ajkai járás, ajkai járási

Alaszka, alaszkai

Alcsi-Holt-Tisza, alcsi-holt-tiszai

Algír (város; arabul Ed-Dzáirr), algíri

Alma-Ata l. Almati 
A szabályzatban:

Mars

Jupiter

Nagy-Göncöl

\section{BOGNER 1939:}

Mars

A szabályzatban:

Jupiter, Vénus, Fiastyúk

MTA 1950:

föld; a Föld (mint égitest)

Göncölszekér

A szabályzatban:

Vénus

Föld

MTA 1954:

Göncölszekér; de: Göncöl szekere hold (égitest), holdja, holddal

Mars (égitest)

DEME-FÁBIÁN 1961:

föld, földje, földdel; csillagászati szakmunkákban: a Föld

Göncölszekér; de: Göncöl szekere

hold, holdja, holddal; csillagászati szakmunkákban: a Hold

Mars (isten és bolygó), Marssal, a Marson;-marsi és marsbeli

SzABÓ T. et al. 1978:

föld, földje, földdel; csillagászati szakmunkákban: a Föld

Göncölszekér; de: Göncöl szekere hold (égitest), holdja, holddal [...] (csillagászati szakmunkákban): a Hold tudományos munkákban: Föld, Nap,

Hold

Göncöl szekere

hold; a Hold (égitest)

Nap

Venus (istennö és bolygó); de: Vénusz:

a murányi Vénusz

nagy medve; de: a Nagymedve

(csillagkép)

nap (égitest), napja; csillagászati szakmunkákban: a Nap

Venus (istennö és bolygó), Venusszal,

a Venuson; - venusi és venusbeli

Vénusz: a milói Vénusz, a murányi

Vénusz

Mars (isten és bolygó), Marssal, a Marson; marsi és marsbeli;

Mars-lakó; de: marslakó

(=különleges) figura

Nagymedve (csillagkép); de: nagy medve 
nap (égitest), napja; csillagászati

szakmunkákban: a Nap
Venus (istennö és bolygó), Venusszal, a Venuson; venusi és venusbeli Vénusz: a milói Vénusz

MTA 1984:

Föld (tulajdonnévként)

Göncölszekér; de: Göncöl szekere

hold (égitest), holdja, holddal; de tulajdonnévként: a Hold

Mars (isten és bolygó), Marssal; marsi és marsbeli

Merkúr (bolygó)

A szabályzatban:

Ikrek, Fiastyúk, Orion, Tejút, Merkúr, Plútó, Vénusz

\section{DEME-FÁBIÁN 1988:}

Föld (tulajdonnévként)

Göncölszekér; de: Göncöl szekere

hold (égitest), holdja, holddal; [...] de tulajdonnévként: a Hold

Mars (isten és bolygó), Marssal, marsi és marsbeli

Merkúr (bolygó), merkúri

nagy medve; de: a Nagymedve

(csillagkép)

\section{DEME-FÁBIÁN-TÓTH 1999:}

nap (égitest), napja; de: a Nap (tulajdonnév)

\section{LACZKÓ-MÁRTONFI 2004:}

Göncölszekér: göncölszekéri

Hold (csillagászati tulajdonnévként) Holdon, holdi || Hold-Föld-távolság

Mars $^{2}$ 'a Naprendszer negyedik bolygója' Marson, marsi $\|$ marsbeli, Mars-év, Mars-expedició, Mars-kutatás, Mars-szonda marslakó 'ürlény; fura alak' Mars-lakó 'Marson élö lény' nap (égitest), napja; de tulajdonnévként: a Nap

Vénusz (bolygó és istennő neve; latinosan: Venus), vénuszi és vénuszbeli; a milói Vénusz, a murányi Vénusz nap (égitest), napja; de tulajdonnévként: a Nap

Venus (istennö), Venusszal, venusi; de: a milói Vénusz, a murányi Vénusz

Vénusz (bolygó), a Vénuszon, vénuszi; Vénusz-felszín
Merkúr: merkúri

Nagy Medve (latinul Ursa maior) nagy medvei

Nap (csillagászati tulajdonnévként) napi || Nap-Föld-távolság | Nap típusú csillag

Vénusz 'a Naprendszer második bolygója'vénuszi || Vénusz-expedició, Vénusz-felszín, Vénusz-rakéta 
A kötet Tanácsadó részében bemutatott kategorizáció: a naprendszer bolygói; csillagképek.

BÁRÁNY 2009:

Föld (tulajdonnévként)

Mars (isten/bolygó)

Göncöl

Merkúr (bolygó)

Göncölszekér

Mérleg (csillagkép)

Göncöl szekere

Nagymedve (csillagkép)

Hold (égitest: a Föld holdja)

Nap

Vénusz (bolygó és istennö neve ma-

vénuszdomb

gyarosan)

vénuszi

Vénusz-átvonulás

Vénusz-rakéta

vénuszbeli

MTA 2015:

Föld (csillagászati tulajdonnévként) földi; Föld körüli pálya

Göncölszekér; de: Göncöl szekere

hold (égitest), holdja, holddal; de tulajdonnévként: a Hold

Mars (isten és bolygó), Marssal;

marsi és marsbeli

Merkúr (bolygó)

Nagy Medve; Nagy Medve-beli

nap (égitest), napja; de csillagászati tulajdonnévként: Nap

Vénusz (istennö és bolygó neve magyarosan), vénuszi és vénuszbeli; milói Vénusz

TÓTH 2017:

Föld (csillagászati tulajdonnévként);

Nagy Medve (csillagkép); Nagy

Föld körüli pálya

Medve-beli

Hold (csillagászati tulajdonnév), holdbeli v. holdbéli; Hold-Föld-távolság

Mars (bolygó), marsbeli; Mars-év,

Mars-kutatás, Mars-szonda

nap (égitest), napja; de csillagászati tulajdonnévként: Nap

Vénusz (istennö és bolygó neve magyarosan), Vénuszon, vénuszi és vénuszbeli; Vénusz-felszín | milói Vénusz

3.6. Intézménynevek. Intézménynevek mindegyik szótárban elöfordulnak.

\section{KELEMEN 1906:}

akadémia (mint köznév): ellenben: a

Magyar Tudományos Akadémia $=a z$

Akadémia 
A függelékben:

Magyar Tudományos Akadémia

Természettudományi Társulat

Első Hazai Takarékpénztár

\section{HORVÁTH 1913:}

akadémia (akademia): föiskola, tudósok társasága; az Akadémia úgy döntött; van két akadémiája;

A szabályzatban:

Vatikán

Nemzeti Szinház

a kir. Kúria

Magyar Tudományos Akadémia, Nemzeti Múzeum, de: az nem akadémia, de ez múzeum

BALASSA 1929:

akadémia, Magyar Tudományos

A szabályzatban:

Magyar Tudományos Akadémia

Kisfaludy Társaság

Természettudományi Társulat

Nemzeti Szinház

Szépmüvészeti Múzeum

BOGNER 1939:

akadémia $g$ = tudós társaság, szakirányú felsöiskola, az Akadémia,

Szerb Tudományos Akadémia,

A szabályzatban:

Királyi Báni Hivatal, Proszvéta Konviktus, Nemzeti Szinház, Első Horvát Takarékpénztár, Fekete Sas

MTA 1950:

Akadémia $=$ A Magyar Tudományos Akadémia; röv.: M. Tud. Akadémia nem hivatalos használatban: nemzeti szinház, székesfehérvári áll. Föreáliskola

a Magyar Tudományos Akadémia röv.: M. T. Akadémia

operaház, az Operaház

Pesti Hazai Első Takarékpénztár

Budapesti grafikai és rokoniparosok fönökegyesülete (mivel nagyon hosszú)

Radich Béla és Társa

Kovács Árpád és Fia

Akadémia (M. T. Akadémia)

Magyar Általános Hitelbank

Bethlen Kollégium

a m. kir. Adóhivatal, a IV. ker. elöljáróság, a központi állampénztár

Magyar Tudományos Akadémia, röv. M. T. Akadémia
Alkotmányozó Gyülés opera, operák; az Opera

Operaház 
A szabályzatban:

Magyar Tudományos Akadémia

Közegészségügyi Intézet

Magyar Nyelvtudományi Társaság

Országos Tervhivatal

MTA 1954:

Akadémia $=$ a Magyar Tudományos Akadémia; röv.: MTA, névelövel: az MTA

A szabályzatban:

Magyar Dolgozók Pártja

Pedagógus Szakszervezet

Magyar Tudományos Akadémia

Ipari Tervezö Intézet

\section{DEME-FÁBIÁN 1961:}

Akadémia (= a Magyar Tudományos Akadémia), az Akadémiában és az Akadémián; - akadémiai

kórház $\mid \leftarrow$ [...] János Kórház és Rendelöintézet (rövidebben: János-

-kórház; [] Benczúr utcai Kórház opera, operája, operái; de: az Opera (= a budapesti operaház) pályaudvar; röv.: pu. $\mid \leftarrow$ [...] Keleti pályaudvar, Gömöri pályaudvar

SzABÓ T. et al. 1978:

pályaudvar: [...] Északi pályaudvar Nemzeti Színház; nemzeti színházi

A szabályzatban:

Román Kommunista Párt

Románia Szocialista Köztársaság Akadémiája

Magyar Tudományos Akadémia

Párttörténeti Intézet

\author{
Szabadság Szálló \\ bölcsészettudományi kar, szentesi \\ földmüvesszövetkezet, mezötúri \\ gépállomás
}

Államvasutak, röv.: MÁV

opera, operája; de: az Opera

Operaház

\section{Oktatásügyi Minisztérium}

Eötvös Loránd Tudományegyetem

Petöfi Sándor Gimnázium

Rudas fürdö, a Rudas fürdöben; - Rudas fürdö $i$

szálló (fn.), szállója, szállói $\mid \leftarrow[\ldots]-$

Gellért-szálló, Opera-szálló (nem

hivatalos nevekként)

szálloda, szállodája, szállodái $\mid \leftarrow A s-$ toria Szálloda, Duna Szálloda, Gellért Szálloda, Opera Szálloda, Park Szálloda (hivatalos intézménynevekként)

szálloda, szállodája, szállodái [...]

Napoca Szálloda

Babeş-Bolyai Tudományegyetem

Nyelvtudományi Intézet

Kriterion Könyvkiadó

Egyetemi Könyvtár

Állami Magyar Színház 
MTA 1984:

akadémia (= föiskola), akadémiája,

opera, operája, operái; de: az Opera akadémiái; de: az Akadémia (=a

(= a budapesti operaház)

Magyar Tudományos Akadémia)

Állami Biztositó (intézménynév); röv.: ÁB

étterem: Kárpátia étterem, Kis Rabló étterem

fürdö [...] Lukács fürdö pályaudvar; röv.: pu. [...] Kelenföldi pályaudvar, a szolnoki pályaudvar szálló (fn.), szállója, szállói; [...] Volga Szálló szálloda, szállodája, szállodái; [...] Gellért Szálloda

kórház [...] Mentőkórház, Sport-

kórház, Margit Kórház, Tétényi

Úti Kórház (intézménynevek)

A szabályzatban bemutatott kategorizáció: hivatalos, teljes és cégszerü nevek; intézmények alárendelt egységei; pályaudvarok, megállóhelyek, repülőterek, mozik, vendéglök, eszpresszók, üzletek, fürdők, temetők stb.; intézményszerü rendezvények, kiállítások, vásárok.

\section{DEME-FÁBIÁN 1988:}

ÁFÉSZ = Általános Fogyasztási és Értékesitési Szövetkezet; de: egy falusi áfészben

Air France (repülőtársaság), az Air

France-szal

Akadémia (= a Magyar Tudományos

Akadémia), az Akadémiában és az Akadémián, akadémiai

állami áruház; de: Úttörö Állami Áruház

államvasutak; de: Magyar Államvasutak; röv.: MÁV

étterem: Kárpátia étterem, Kis Rabló étterem, Vörös Rák étterem

fürdö [...] Lukács fürdö kórház [...] Benczúr Utcai Kórház, Fövárosi János Kórház és Rendelöintézet, [...] Mentőkórház, Sportkórház, Tétényi Úti Kórház Opera (= a budapesti operaház) operaház; de: Magyar Állami Operaház pályaudvar; röv.: pu. [...] Budapest Nyugati pályaudvar, Kelenföldi pályaudvar, rendezö pályaudvar; a szolnoki pályaudvar szálló (fn.), szállója, szállói; [...] Erzsébet Szálló szálloda, szállodája, szállodái; szállodaipar | Nemzeti Szálloda, Volga Szálloda

\section{DEME-FÁBIÁN-TÓTH 1999:}

állami áruház

kórház [...] Madarász Utcai Gyermekkórház és Rendelöintézet, Mentőkórház, Sportkórház, Szent Imre Kórház pályaudvar; röv.: pu. [...] Kelenföldi pályaudvar, Nyugati pályaudvar, rendezö pályaudvar, a szolnoki pályaudvar szálló (fn.), szállója, szállói; [...] Stadion Szálló

szálloda, szállodája, szállodái; szállodaipar | Astoria Szálloda, Nemzeti Szálloda 
LACZKÓ-MÁRTONFI 2004:

Ágoston-rend

Akácos kisvendéglö: Akácos kisvendéglöi
Akadémia 'Magyar Tudományos Aka- démia'akadémiai || az Akadémia levelezö tagja, az Akadémia ren- des tagja

A kötet Tanácsadó részében bemutatott kategorizáció: hivatalos nevek; rövid alakok; alárendelt egységek; intézményszerű rendezvények, kiállítások, vásárok.

BÁRÁNY 2009:

Adó-és Pénzügyi Ellenörzési Hivatal Ágoston-rend

Ágoston-rendi
Adó- és Pénzügyi Ellenörzési Hivatal
l. Nemzeti Adó- és Vámhivatal; röv.: $A P E H$
Alitalia (légitársaság), az Alitaliánál

MTA 2015 igen bő választékot ad:

Agrártudományi Egyetem (intézménynévként)

Akadémia (a Magyar Tudományos Akadémia)

akadémia (= föiskola), akadémiája, akadémiái; de: az Akadémia (=a Magyar Tudományos Akadémia) operaház; de: Magyar Állami Operaház; rövid névváltozattal: Operaház v. Opera

TóTH 2017:

$$
\begin{aligned}
& \text { adóhivatal; Nemzeti Adó- és Vámhiva- } \\
& \text { tal; röv.: } N A V \\
& \text { ÁÉSZ = Áltatur Fogyasztúsi és Ér- } \\
& \text { tékesitési Szövetkezet; de: egy fa- } \\
& \text { tusiáfészen } \\
& \text { Akadémia (= a Magyar Tudományos } \\
& \text { Akadémia), az Akadémiában és az } \\
& \text { Akadémián, akadémiai; az Aka- } \\
& \text { démia levelezö tagja } \\
& \text { úllami árúz } \\
& \text { államvasút; de: Magyar Államvas- } \\
& \text { utak; röv.: MÁV } \\
& \text { étterem, étterme; étteremlánc | Bíró } \\
& \text { Háza Etterem és Panzió, Bíró Háza }
\end{aligned}
$$

étterem és panzióbeli, Kárpátia étterem, Kis Rabló étterem kórház [...] intézménynév részeként:

Sportkórház, Szent Margit Kórház pályaudvar; röv.: pu. [...] rendezö pályaudvar, szolnoki pályaudvar;

Kelenföldi pályaudvar, Nyugati pályaudvar szálló (fn.), szállója, szállói; [...]

Kastélykert Szálló szálloda, szállodája, szállodái; [...] |

Erzsébet Szálloda

3.7. Márkanevek. Márkanevek 1961 óta fordulnak elő a helyesírási szótárakban; Kelemen 1906, HoRVÁTH 1913, BALASSA 1929, MTA 1950 és MTA 1954 tehát nem mutat be márkaneveket.

Először DEME-FÁBIÁN 1961-ben tünnek fel: 
Ford, Forddal $\mid \rightarrow$ Ford-gyár $\mid \leftarrow$ van egy Fordja
Pobeda, Pobedával: beült a Pobedába $\rightarrow$ Pobeda autó

SzABÓ T. et al. 1978:

autó [...] Dacia autó

MTA 1984:

autó [...] Škoda autó

Mercédesz (nöi név), Mercédesszel; de: egy Mercedes (márkanév)

A szabályzatban:

Ultra, Trabant, Fabulon, Vegacillin; Alfa Romeo, Coca-Cola narancsital, meggylé; kecskeméti barack, tokaji bor ${ }^{7}$

Omnia kávé, Panangin tabletta, Odol fogkrém; Tomi Mat mosópor

DEME-FÁBIÁN 1988:

Alfa Romeo (autómárka)

autó [...] Moszkvics autó, Škoda autó,

Ford, Forddal; Ford-gyár | van egy

Fordja

Wartburg kombi autó

Mercedes (márkanév), Mercedesszel

Coca-Cola, Coca-Colát, Coca-

Colával, coca-colás; Coca-Cola-

-szerü

DEME-FÁBIÁN-TÓTH 1999:

autó [...] FIAT v. Fiat autó, Opel

autó, Škoda autó

LACZKÓ-MÁRTONFI 2004:

Adidas [adidasz] adidasos

Kalasnyikov: kalasnyikovos

Adobe [edobi] $\{A \cdot d o-b e\}$ adobes

A szótár Tanácsadó részében:

Sony

Sába sonka

Piros Arany

Benetton

Egyél Egyet!

Hohes C

Visa Electron

${ }^{7}$ L. a 193. pont második bekezdésének állásfoglalását: „A nem márkanévként használt, többnyire a termék anyagára vagy származási helyére utaló nevekben a tagokat kis kezdőbetűvel írjuk: narancsital, meggylé; kecskeméti barack, tokaji bor; stb. - Címkén, hirdetésen stb., alakulatkezdő helyzetben az első tagot természetesen nagybetüvel kezdjük: Kecskeméti barack stb." 
BÁRÁNY 2009:

Mercedes (márkanév)

MTA 2015:

Excel (= táblázatkezelö program);

Excel-tábla

TÓTH 2017:

Alfa Romeo (autómárka), Alfa

Romeó-s

autó $[\ldots]$ Škoda autó

Mercédesz (utónév), Mercédesszel; de: Mercedes (márkanév), Mercedesszel

Ford, Forddal; Ford modell $\mid$ Henry

Ford

3.8. Kitüntetésnevek és díjnevek. Kitüntetés- vagy díjnév elöször 1913-ban tünik fel (KELEMEN 1906-ban tehát még nem), de ekkor még csak a kis kezdőbetüs térdszalagrend. 1950-től tulajdonnévi példák is megjelennek.

HORVÁTH 1913 és BALASSA 1929:

térdszalag(rend)

MTA 1950:

Kossuth-dij

Szabadság-érdemrend

MTA 1954:

Kossuth-dij

Kossuth-dijas

DEME-FÁBIÁN 1961:

Kossuth-dij

térdszalagrend

SZABÓ T. et al. 1978:

Állami Díj; állami dijas

térd [...] térdszalagrend

dij [...] Nobel-dij

MTA 1984:

dij [...] Jászai Mari-díj, Nobel-dij; Állami Díj

díjas; Jászai Mari-dijas, Nobel-dijas;

SZOT-dijas; állami dijas

Kossuth-dij, Kossuth-dijas

A szabályzatban bemutatott kategorizáció: tulajdonnévi előtagúak; több különírt közszóból állók; kitüntetések és díjak fokozatai, típusai. 
DEME-FÁBIÁN 1988:

dij [...] Jászai Mari-dij, Kossuth-dij, Nobel-dij; Állami Díj

Kossuth [...] Kossuth-dij, Kossuth-dijas

dijas; Jászai Mari-dijas, Nobel-dijas;

SZOT-dijas; állami dijas

DEME-FÁBIÁN-TóTH 1999 hűen követi DEME-FÁBIÁN 1988-at.

LACZKÓ-MÁRTONFI 2004 - az altípusok jelentős bővülése a rendszerváltás hozta robbanásszerü nyelvhasználati változás következtében:

Corvin-lánc: Corvin láncos

dij [...] Bartók Béla-Pásztory Ditta-

-dij, Baumgartner-dij, [...]

Grammy-dij [...] | Állami Dij, [...]

Mécs László irodalmi dij

A szótár Tanácsadó részében:

Citromdij (névvé vált dijtípus)

Eötvös Loránd-emlékérem; Alföld-dijj;

MIE-emlékérem

kémiai Nobel-dij; béke-Nobel-dij

Gundel-dij, de: Gundel müvészeti dij

a Francia Köztársaság Becsületrendje; Állami Díj

BÁRÁNY 2009:

Kossuth-dij

MTA 2015:

Akadémiai Aranyérem

dij [...] Sajtódij, Toleranciadíj; Jászai

Mari-dij, Nobel-dij; Állami Díj;

Pro Universitate dij, Pro Urbe dij pro [...] Pro Urbe Dij

térdszalag || térdszalagrend,

térdszalagsérülés

Életfa dijj; Pro Cultura Hungarica emlékplakett tanári Delfin dij

Magyar Köztársasági Arany Érdemkereszt

Budapest Tájfutó Sportjáért dij

Kossuth-dijas

dijas; Jászai Mari-dijas, Nobel-dijas; állami dijas

A szabályzat sokat merít LACZKÓ-MÁRTONFI 2004-ből.

То́тн 2017:

Akadémiai Aranyérem

dij [...] tulajdonnév részeként: Sajtódij, Toleranciadij; Jászai Mari-dij, Kossuth-dij, Nobel-dij; Állami Díj; Pro Universitate dij, Pro Urbe dij dijas; Jászai Mari-dijas, Nobel-dijas; állami dijas

Kossuth-dij, Kossuth-dijas 
3.9. Címek. Címek mindegyik szótárban előfordulnak.

KELEMEN 1906:

az Odisszea v. Odysseia

A függelékben:

Magyar Nyelvtan

Törökországi Levelek

Budapesti Közlöny

Vasárnapi Újság

A kösziviu ember fiai

Zalán futása vagy Zalán Futása

Buda halála vagy Buda Halála

HORVÁTH 1913:

Friss Ujság

Odisszea (Odyssea): Odisszeus (Odys-

Vasárnapi Ujság

seus) bolyongásait leíró eposz címe

A szabályzatban:

Utazás a föld körül

Vasárnapi Ujság

a Falu rossza [!]

Kewlari búcsú

Magyar Nyelvör

BALASSA 1929:

szózat; a Szózat

A szabályzatban:

Budapesti Szemle

Magyarország és a Nagyvilág

A köszivü ember fiai

Fenn az ernyö, nincsen kas

Pesti Napló

A falu rossza

Zalán futása

Gondolatok a könyvtárban

BOGNER 1939:

szózat; a Szózat

A szabályzatban:

A Két Fogoly, Hitel, Világ, Ifjúság,

Kalangya, A Mi Irodalmunk, de:

„A mi irodalmunk"

MTA 1950:

Szózat (Vörösmarty költeménye)

A szabályzatban:

Szabad Nép, Szabad Ifjúság, Társadalmi Szemle, Élet és Tudomány, Magyar Nyelv

«Az acélt megedzik», "A fordulat éve», «Ismét magyar lett a magyar»

Buda Halála, Az Ifjú Gárda, Nemzeti Dal 
MTA 1954:

Odisszea

A szabályzatban:

Szabad Nép

A leninizmus kérdései

DEME-FÁBIÁN 1961:

Aeneis, az Aeneisszel; - aeneisi nemzeti dal; de: a költö maga mondta el a Nemzeti dalt

népszabadság; de: Népszabadság (újságcím)

SzABÓ T. et al. 1978:

biblia [...] Biblia (irodalmi mü)
Nemzeti dal

Elöszó

Népszava (újságcim); de: a nép szava Odisszea (hösköltemény; görögösen

Odüsszeia), az Odisszeában; odisszeai
Odisszea (hösköltemény; görögösen

Odüsszeia), az Odisszeában;

odisszeai

MTA 1984:

$\begin{array}{cc}\text { Nép-: Népszabadság, Népszava (újság- } & \text { odisszea (= hányattatás, bolyongás); } \\ \text { címek); Népszinház; Nép-sziget } & \text { de: Odisszea (hösköltemény; gö- } \\ & \text { rögösen: Odüsszeia) }\end{array}$

A szabályzatban bemutatott kategorizáció: állandó címek - újságok, hetilapok és folyóiratok címe; egyedi címek - költői müvek, könyvek, értekezések, cikkek, képek, szobrok, zenemüvek, müsorszámok stb.

DEME-FÁBIÁN 1988:

Aeneis, az Aeneisszel, aeneisi; Aeneis-beli hös

Aida (zenemü), Aida-beli

nemzeti dal; de: a költö maga mondta el a Nemzeti dalt

Nép-; Népszabadság, Népszava (újságcímek); Népszinház; Nép-sziget

odisszea (= hányattatás, bolyongás);

de: Odisszea (hösköltemény; gö-

rögösen Odüsszeia)

szózat, szózata; Szózat (verscím)

DEME-FÁBIÁN-TÓTH 1999:

szózat, szózata; de: Szózat (verscím)

LACZKÓ-MÁRTONFI 2004:

A Dunánál címü vers

Aeneis [éneisz] \{Ae-ne-is\} aeneisi

Agnus Dei

Aida [ajda] $\{$ Ai-da $\}$ aidai $\|$ Aida-

-elöadás

A Hét

Ajurvéda: Ajurvéda-beli || ájurvédikus 
A kötet Tanácsadó részében bemutatott kategorizáció: állandó címek; melléklet- és rovatcímek, tévé- és rádiómüsorok állandó címei; internetes portálok címei; egyedi címek.

BÁRÁNY 2009:

Aeneis

A közúti közlekedés szabályai (rendelet cime)

MTA 2015:

Aeneis, aeneisi; Aeneis-beli hös

Nemzeti alaptanterv; röv.: NAT

\author{
Odüsszeia, Odüsszea-beli \\ szózat, szózata; de: Szózat (verscím)
}

TóTH 2017:

Aeneis, az Aeneisszel, aeneisi; elv.: Ae-ne-is; Aeneis-beli hös

Aida (zenemü), Aida-beli; Aida-

-bemutató

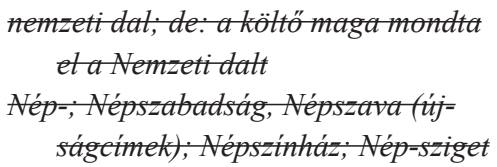

3.10. Egyéb tulajdonnevek. Az egyéb tulajdonnevek megjelenése - a dolog természetéből adódóan - meglehetősen ad hocnak tünik.

KELEMEN 1906, HORVÁTH 1913 és BALASSA 1929 egyike sem foglalkozik egyéb tulajdonnevekkel. Az MTA 1950-ben csak a szabályzatban jelennek meg egyéb tulajdonnevek. Az akadémiai helyesírási szabályzat 1879-1950 közötti kiadásaiban ugyanis - némileg eltérő szövegváltozatokkal - szerepel az alábbi kitétel: „Természettudományi munkákban az é g i te s te k és j e g y e k neveit egyöntetüség és könnyebb érthetőség kedvéért nagy kezdőbetüvel írják: Merkur, Venus, Föld (Tellus), Nap (Sol), Kaszás, Fiastyúk, Kos, Bika; - a földtanban a képződmények neveit: Kréta, Köszén, Jura, Trias stb.,valamint más tárgyi tulajdonneveket is, ha különös kiemelésük szükségesnek mutatkozik, pl. a kőzettanban a kőzetek, az ásványtanban az ásványfajok, a vegytanban az elemek nevét stb. [kiemelések az eredetiben]" (MTA 1943: 42).

MTA 1954: ekkortól 1984-ig két eseménynév, a Nagy Októberi Szocialista Forradalom és a Nagy Honvédö Háború tulajdonnévként, kivételesen, nagy kezdőbetüvel íródik. A manapság elég gyakori nagy kezdőbetüs eseménynévírást a helyesírási szabályzatok legfeljebb eltürik, a szótárak semmiképp se propagálják.

DEME-FÁBIÁN 1961:

Nagy Honvédö Háború; - nagy hon-

Nagy Októberi Szocialista Forradalom védö háborúbeli

SzABÓ T. et al. 1978:

Nagy Honvédö Háború; nagy honvédő $\quad$ Nagy Októberi Szocialista Forradalom háborúbeli

MTA 1984 visszavonja ez utóbbiak tulajdonnévi státusát:

nagy honvédö háború

nagy októberi szocialista forradalom 
DEME-FÁBIÁN 1988 óta a szótárakban időről időre fel-feltünnek számítógépes programozási nyelvek nevei:

Algol nyelv (a számitástechnikában)

DEME-FÁBIÁN-TÓTH 1999:

Pascal nyelv (számitógépi programnyelv)

Komplex kézikönyv lévén LACZKÓ-MÁRTONFI 2004 a többinél részletesebben mutatja be a tulajdonnévi kategóriákat és alkategóriákat; ezekről több helyütt tettünk említést. Az e pontban tárgyalt típusok is megjelennek a szótári részben:

$\begin{array}{cc}\text { BASIC [bézik] \{BA.SIC\} 〈Beginner’s } & \text { nagy [...] nagy honvédö háború [...] } \\ \text { All-purpose Symbolic Instruction } & \text { nagy októberi szocialista forrada- } \\ \text { Code 'Kezdök Általános Célú } & \text { lom } \\ \text { Szimbolikus Utasitáskódja'〉 } & \text { Pascal }^{2} \text { (programnyelv) [paszkál] } \\ \text { BASIC-kel, BASIC-es } \| \text { BASIC- } & \text { pascali } \| \text { Pascal-program } \mid \text { Pascal } \\ \text {-program } \mid \text { BASIC nyelv } \| \rightarrow \mid \text { Vi- } & \text { nyelv }\end{array}$

BÁRÁNY 2009 és MTA 2015 nem foglalkozik egyéb tulajdonnevekkel.

То́тн 2017:

Pascal nyelv (programnyelv)

4. Összegzés. A magyar helyesírás történetében eddig 15 (önálló münek tekinthető) szótár jelent meg, az első 1906-ban. Ezeket tekintettük át a tulajdonnevek feldolgozása szempontjából. Általánosságban megállapíthattuk, hogy minden szótár tartalmaz tulajdonneveket, toldalékolási tudnivalókkal. A szótárak mérete egyre nő, így a tulajdonnévi állomány is bővül. Ezzel párhuzamosan a szótári apparátus is folyamatosan érlelödik, fejlődik, az 1950-es szabályzat óta egyértelmüen szervesen.

A bemutatott tulajdonnévi kategóriák is fokozatosan számosodnak: személynevek, földrajzi nevek, csillagászati nevek, intézménynevek és címek mindegyik szótárban elöfordulnak. Kitüntetés- vagy díjnév elöször 1913-ban tünik fel, előbb csak kis kezdőbetüvel, 1950-től tulajdonnévi példákkal is. Márkanevek 1961 óta fordulnak elő a helyesírási szótárakban. Állatnevek 1913-ban jelennek meg először, de - noha 1929 óta a szabályzatokban előfordulnak nagy kezdőbetüs állatnevek - 1950-ig a szótárakban kizárólag kis kezdőbetüvel; nagy kezdőbetüs állatnévi példák szótárban csak 2004 óta bukkannak fel. Tárgynevekre példát először 1999-ből találni, bár a nagy kezdőbetű itt inkább a szakralitás jelölöje, a tárgynévi kategória 2004-től egyértelmü csupán.

A kisbetü-nagybetű átcsapás nem csupán a helyesírási szótárak, hanem az akadémiai helyesírás egész történetén végigvonul. Az 1832-es első szabályzat még az intézményneveket is csak korlátozottan tartotta tulajdonnévnek, például: magyar tudós Társaság. Az eltelt szűk két évszázad során folyamatosan nőtt a nagy kezdőbetűs, azaz a helyesírás által tulajdonnévnek tartott elemek aránya. Ezt is tükrözheti az állatnevekről és díjnevekről tett fenti megfigyelés. Ennek a fajta elmozdulásnak a hátterében álló okok ugyanakkor 
vélhetőleg elsősorban közéletiek (a 19. század elején a minden főnevet nagy kezdőbetüvel írni rendelő német helyesírástól való minél nagyobb elkülönböződés igénye) és szociálpszichológiaiak (a dolgoknak tulajdonított szubjektív fontosság ikonikus megjelenítése), így ezek elemzése szétfeszítené egy nyelvészeti tárgyú írás kereteit.

\section{Felhasznált források}

BALASSA JÓZSEF 1929. Az egységes magyar helyesírás szótára és szabályai. Budapesti Korrektorok és Revizorok Köre, Budapest.

BÁRÁNY MARGIT 2009. Akadémiai helyesirási szótár. Akadémiai Kiadó, Budapest.

BOGNER JÓZSEF 1939. A magyar helyesírás szabályai és szótára. Jugoszláviai Magyar Népkönyvtár. Globus Nyomda, Petrovgrád [= Nagybecskerek].

DEME LÁSZLÓ - FÁBIÁN PÁL 1961. Helyesirási tanácsadó szótár. Terra, Budapest.

DEME LÁSZLó - FÁBIÁN PÁL 1988. Helyesirási kéziszótár. Akadémiai Kiadó, Budapest.

DeME LÁsZló - FÁBIÁN PÁL - Tóth ETELKA 1999. Magyar helyesírási szótár. Akadémiai Kiadó, Budapest.

HORVÁTH ENDRE 1913. A magyar helyesírás szótára és szabályai. Az iskolai helyesírás alapján. Athenaeum, Budapest.

KELEMEN BÉLA 1906. A magyar helyesírás kis szótára. A hivatalos iskolai helyesirás alapján. Athenaeum, Budapest.

LACZKÓ KRISZTINA - MÁRTONFI ATTILA 2004. Helyesírás. Osiris Kiadó, Budapest.

MAgYAR TUDOMÁNYOS AKADÉMIA 1943. A magyar helyesirás szabályai. 8., átdolgozott és bővített kiadás. Akadémiai Kiadó, Budapest.

MAGYAR TUDOMÁNYOS AKADÉMIA 1950. A magyar helyesírás szabályai. 9., átdolgozott és bővített kiadás. Akadémiai Kiadó, Budapest.

MAgYar TudOMÁNYOS AKAdÉMIA 1954. A magyar helyesírás szabályai. 10., átdolgozott és bővített kiadás. Akadémiai Kiadó, Budapest.

MAgYar TUdOMÁNYOS AKAdÉMIA 1984. A magyar helyesírás szabályai. 11. kiadás. Akadémiai Kiadó, Budapest.

MAgYar TudomÁNYOs AKAdÉmia 2015. A magyar helyesírás szabályai. 12. kiadás. Akadémiai Kiadó, Budapest.

Szabó T. Attila - Balogh Dezső - GÁlffy Mózes - Kelemen Béla szerk. 1978. Magyar helyesirási szótár. Kriterion Könyvkiadó, Bukarest.

TóTH ETELKA 2017. Magyar helyesírási szótár. A magyar helyesirrás szabályai tizenkettedik kiadása szerint. Akadémiai Kiadó, Budapest.

\section{Hivatkozott irodalom}

FÁBIÁN PÁL szerk. 1962. A Helyesírási Bizottság újabb határozatai. MTA I. Osztály Közleményei 19: 277-87.

FÁBIÁN PÁL szerk. 1972. A Helyesírási Bizottság 1959-1961. évi határozatai. In: TIMKÓ GYÖRGY szerk., Helyesírási és tipográfiai tanácsadó. 2. kiadás. Nyomdaipari Egyesülés, Budapest. 60-72.

MÁRTONFI ATTILA

ORCID: https://orcid.org/0000-0001-9972-4305

Budapest 


\section{Attila Mártonfi, Proper names in Hungarian spelling dictionaries}

The paper provides a review of every spelling dictionary of the Hungarian standard, excluding terminological, transcriptional, and educational works, however, considering attached regulatory sections and appendices. The general observations are the following: Every spelling dictionary contains proper names. Over time, dictionaries have become more and more detailed; hence the onomastic material within them has also grown. The lexicographical apparatus has become richer over time. While it was slightly chaotic at the beginning of the examined period, then it became overcomplicated and was finally cleaned up made the 1980s. Organic development can be observed from the 1950s. At times, new onomastic categories appeared in the dictionaries. Anthroponyms, toponyms, astronomical names, names of institutions, and titles occur in every dictionary. Names of honors, prizes, or awards appeared for the first time as proper names in 1950. Brand names have been present in dictionaries since 1961. The occurrence of the names of animals is the most hectic: dictionaries between 1913 and 1950 handled them as common nouns. Since 1929 regulations have considered them proper names; the first capitalized examples in dictionaries only appeared in 2004. The names of objects have been listed since 1999, however the first cases were capitalized because of their sacred nature. The category has been used consciously since 2004 . Miscellaneous proper names also appear ad hoc in the dictionaries. 